\title{
Rare and endangered species in communities of the Adenostylion alliariae alliance in the Carpathian Mountains
}

Alina Stachurska-Swakoń

\begin{abstract}
Rare and endangered species in communities of the Adenostylion alliariae alliance in the Carpathian Mountains. - Čas. Slez. Muz. Opava (A), 60: 127-134, 2011.

Abstract: The Adenostylion alliariae alliance (Mulgedio-Aconitetea class) comprises plant communities which grow optimally in the subalpine zone of the European mountain ranges. The flora of these communities consists of more than four hundred taxa of vascular plants. Some of the diagnostic species are valuable and rare, either in the Carpathians as a whole or in the countries in which the Carpathians lie. In the flora of the plant communities studied, five taxa are indexed in the Polish Red Book of Endangered Plant Species, thirteen taxa are endemic to the Carpathians, and fourteen represent the eastern biogeographical element in the Polish flora. Two taxa are listed in the Annex II of the Habitats Directive.

Key words: Carpathians, tall-herbs, endemics, threatened species, biodiversity.
\end{abstract}

\section{Introduction}

The alliance Adenostylion alliariae Br.-B1. 1926 belongs to the class MulgedioAconitetea Hadač et Klika in Klika 1948, (syn. Betulo-Adenostyletea Br.-B1. 1948). The alliance comprises plant communities which grow optimally in the subalpine zone of the European mountain ranges. These assemblages develop under specific microclimatic and edaphic conditions. They prefer habitats with fertile soil and an abundant water supply lying above the upper forest limit. These plant communities could be also found along streams in the mountain forest zones (Matuszkiewicz 2005; Pawłowski 1972a).

In the Carpathian Mts, there are thirty distinct plant communities which are assigned to the Adenostylion alliariae alliance. Seventeen of them are at the association level, nine are at the subassociation level, and four are at the community level (Stachurska-Swakon 2009a). These communities consist of the rich flora enclosing more than four hundred taxa of vascular plants. Some of the key species are valuable and rare, either in the Carpathians as a whole or in the countries in which the Carpathians lie. This indicates that tall-herb communities play an important role in maintaining biodiversity in the mountains.

The aim of this study was to compile a list of rare and endangered plant taxa that can be found in communities of the Adenostylion alliariae alliance in terms of their ecological status, their geographical distribution, and the range of habitats in which they are encountered. The species selected for this study included the following:

- species threatened in Poland which are presently included in the Polish Red Book of Endangered Plant Species (Kaźmierczakowa \& Zarzycki 2001);

- species which are either endemic or subendemic to the Carpathian Mts (Mitka 2003, 2005; Mitka \& Nowosad 2002; Pawłowska 1953, 1972; Pawłowski 1972b; Piękoś-Mirkowa et al. 1996; Zemanek 1991, 2005; Zemanek \& Winnicki 1999);

- species which are characteristic to the Eastern Carpathians and Balkans (Eastern CarpathianBalkan species); and

- species which represent eastern biogeographical element in the Polish flora (Zemanek 1991, 2005; Zemanek \& Winnicki 1999).

Aposeris foetida, Lathyrus laevigatus, and Glechoma hirsuta were not included in the study, even though they are considered as eastern biogeographical element in the Polish flora. Aposeris foetida is distributed in the Western Carpathians and in the Lublin highlands (Zając \& Zając 2001). Lathyrus laevigatus can be found in the Małopolska highlands, the Lublin highlands, and the Suwałki region (Zając \& Zając 2001) and occurs in the Alps (Aeschimann et al. 2004). Glechoma hirsuta is recently regarded as a weak eastern indicator in Polish flora. 
This species is distributed in the Western Carpathians as far west as the Silesian highlands. It also has their localities in the Małopolska highlands and the Białowieża National Park (Zając \& Zając 2001).

Symphytum cordatum, Pan-Carpathian subendemic species, is also not included in the study. This species is widely distributed and common throughout the Carpathians (Eastern and large part of the Western Carpathians) and extending to the neighbouring areas (Pawłowski 1961; Zając \& Zając 2001).

\section{Materials and methods}

The present study was based on phytosociological relevés from published and unpublished phytosociological studies of the Carpathian Mts, e.g. Balcerkiewicz 1984; Balcerkiewicz \& Pawlak 2004; Boşcaiu 1971; Coldea 1990, 1991; Deyl 1940; Hadač 1956; Fink 1977; Kliment et al. 2007; Kornaś \& Medwecka-Kornaś 1967; Krajčiová-Šibíková et al. 2005; Malinovsky \& Kricsfalusy 2000; Oltean \& Dihoru 1986; Pawłowski \& Walas 1949; Pawłowski \& Stecki 1927; Pawłowski et al. 1928; Šeffer \& Šefferová 1989; Stachurska-Swakoń 2008, 2009b; Stuchlik 1968; Szafer \& Sokołowski 1927; Szafer et al. 1923, 1927; Walas 1933; Wilczek 2006; Winnicki 1999. Information on taxonomy, ecological status, geographical distribution and habitat range were extracted from various general studies and detailed papers, e.g. Assyov \& Petrova 2006; Balazs 1938-1939; Dostal 1989; Hegi 1958; Hultén 1968; Hultén \& Fries 1986; Jalas \& Suominen 1986, 1989; Malinovsky 1980; Meusel et al. 1978; Meusel \& Jager 1992; Pacyna \& Piękoś 1968; Pawłowski 1961; PiękośMirkowa \& Łobarzewska 1990; Prokudin 1999; Stachurska-Swakoń 2009b, c; Sudnik-Wójcikowska \& Werblan-Jakubiec 2004; Zarzycki \& Szelag 2006; Zemanek \& Winnicki 1999. The syntaxonomy of the Adenostylion alliariae alliance was taken from the study of Stachurska-Swakon 2009a.

\section{Species threatened in Poland}

\section{Aconitum firmum Rchb. subsp. moravicum Skalický}

This subspecies is endemic to the Western Carpathians, and can be found in Poland, Slovakia and the Czech Republic. It is listed as vulnerable in the Polish Red Book, and is included in Annex II of the Habitats Directive. This subspecies and Aconitum firmum subsp. firmum are the main components of the association Aconitetum firmi in Poland and Slovakia. It also can be found in other tall-herb communities from the Adenostylion alliance including: Adenostylo alliariae-Athyrietum alpestris (Slovakia), Petasiteto kablikiani-Senecietum hercynicae (Slovakia), Ranunculo platanifolii-Adenostyletum alliariae (Poland, Slovakia) (Mitka 2003).

\section{Aconitum lasiocarpum (Rchb.) Gáyer}

This species is endemic to the Carpathian Mountains and subendemic to the Eastern Carpathians. The species comprises two subspecies: subsp. lasiocarpum and subsp. kotulae. These subspecies are found in the Eastern Carpathians, and to a lesser extent in the Western Carpathians.

Aconitum lasiocarpum is listed as vulnerable in the Polish Red Book, in the Red List of Vascular Plants in Poland (Zarzycki \& Szeląg 2006), and in the Carpathian List of Endangered Species (Witkowski et al. 2003).

Aconitum lasiocarpum can be found in several tall-herb associations: Adenostylo-Doronicetum (Romania), Cirsio waldsteinii-Heracleetum transsilvanici (Romania), Heracleo-palmati-Rumicetum alpinii (Romania); Trollio altissimae-Knautietum dipsacifoliae (Poland) (Coldea 1990, 1991; Oltean \& Dihoru 1986; StachurskaSwakon 2009b; Winnicki 1999).

At lower altitudes, Aconitum lasiocarpum grows in deciduous forests and wet meadows (Mitka 2003).

\section{Campanula serrata (Kit.) Henrych}

This species is endemic to the Carpathians. It can be found rarely in the whole range of the Carpathian Mountains. It is listed as vulnerable in the Polish Red Book, and it is included in the Annex II of the Habitats Directive as priority species.

Campanula serrrata is a multizonal mountain species which occurs in various non-forest communities. It is characteristic species to the Campanulo serratae-Agrostietum capillaris association. In the sub-alpine zone it usually grows in the tall-grass vegetation and in the bilberry heath (Coldea 1991, Kliment et al. 2007). In tallherb communities it can be found in: Aconitetum firmi (Slovakia), Diantho compacti-Hypericetum maculatii (Poland), Geranio robertiani-Delphinietum elati (Slovakia), Ranunculo platanifolii-Adenostyletum alliariae (Slovakia), Trollio altissimae-Knautietum dipsacifoliae (Poland) (Kliment et al. 2007; Winnicki 1999). 


\section{Cortusa matthioli L.}

This European species with disjunctive range occurs in the Alps, Carpathians, Ural and it has dispersed localities in the north-eastern Europe. It is listed as rare - potentially endangered in the Polish Red Book and in the Red List of Vascular Plants in Poland (Zarzycki \& Szelag 2006).

Cortusa matthioli occurs in the habitats associated with running water, most frequently in flush communities. In tall-herb communities it can be found in: Aconitetum firmi (Slovakia), Arunco-Doronicetum austriaci (Poland), Geranio robertiani-Delphinietum elati (Slovakia), Cirsio waldsteinii-Heracleetum transsilvanici (Romania) Petasiteto kablikiani-Senecietum hercynicae (Slovakia) (Fink 1977; Kliment et al. 2007; Kornaś \& Medwecka-Kornaś 1967).

\section{Centaurea kotschyana Heuff.}

This is Eastern Carpathian-Balkan species which occurs in the Eastern Carpathians, Southern Carpathians and in the Balkans. It is listed as rare in the Polish Red Book and in the Red List of Vascular Plants in Poland.

This is subalpine species which grows mainly in the association Trollio altissimae-Knautietum dipsacifoliae in the Western Bieszczady Mts. It also occurs in Diantho compacti-Hypericetum maculati (Poland) and Ranunculo platanifolii-Adenostyletum alliariae (Ukraine) (Malinovsky \& Kricsfalusy 2000; Winnicki 1999).

\section{Endemics and subendemics to the Carpathians}

Aconitum moldavicum Hacq. subsp. hosteanum (Schur) Graebn. \& P.Graebn.

This subspecies is subendemic to the Eastern and Southern Carpathians.

This is montane species which occurs in moist habitats. It can be found in the tall-herb communities in: Aconitetum taurici (Romania), Adenostylo-Doronicetum (Romania), Cirsio waldsteinii-Heracleetum transsilvanici (Ukraine, Romania), Ranunculo platanifolii- Adenostyletum alliariae (Ukraine) (Coldea 1991; Malinovsky \& Kricsfalusy 2000; Pawłowski \& Walas 1949).

\section{Centaurea mollis Waldst. et Kit.} Croatia.

This species is subendemic to the Carpathian Mts. It is reported outside of the Carpathians only from

This is multizonal mountain species which grows in various non-forest communities. In tall-herb communities it can be found in: Aconitetum firmi (Slovakia), Geranio robertiani-Delphinietum elati (Slovakia), Petasiteto kablikiani-Senecietum hercynicae (Slovakia), Ranunculo platanifolii-Adenostyletum alliariae (Ukraine), Trollio altissimae-Knautietum dipsacifoliae (Poland) (Deyl 1940; Kliment et al. 2007; Malinovsky \& Kricsfalusy 2000; Pawłowski \& Walas 1949, Winnicki 1999).

\section{Delphinium oxysepalum Borb. et Pax}

This species is endemic to the Western Carpathians. Outside of the Tatra Mts. it occurs in the massif of the Vel'ký Choč, Malá Fatra Mts., Nízke Tatry Mts. and Muránska Planina.

This is subalpine species, it grows in the Aconitetum firmi association in the Tatra Mts. (Poland, Slovakia) (Kliment 2007; Pawłowski et al. 1928).

\section{Dentaria glandulosa Waldst. et Kit.}

This species is subendemic to the Carpathians. It is common and widespread throughout the Western and Eastern Carpathians.

This is montane species which is characteristic to the association Dentario glandulosae-Fagetum. It is found in tall-herb communities at lower altitudes, mainly in Arunco-Doronicetum austriaci (Poland) (Kornaś \& Medwecka-Kornaś 1967; Wilczek 2006).

\section{Leucanthemum waldsteinii (Sch. Bip.) Pouzar}

This species is subendemic to the Carpathians. It is common and widespread throughout the whole Carpathians and it has isolated localities in Bosnia.

This is multizonal mountain species which occurs in various tall-herb communities: Aconitetum firmi (Poland, Slovakia), Aconitetum taurici (Romania), Adenostylo alliariae-Athyrietum alpestris (Slovakia), Adenostylo alliariae-Doronicetum austriaci (Romania), Arunco-Doronicetum austriaci (Poland), Bryo pseudotriquetri-Chaerophylletum hirsuti (Slovakia), Chaerophyllo hirsuti-Cicerbitetum alpinae (Slovakia), Cirsio waldsteinii-Heracleetum transsilvanici (Romania), Petasiteto kablikiani-Senecietum hercynicae (Slovakia), Ranunculo platanifolii-Adenostyletum alliariae (Poland, Slovakia, Ukraine), Trollio altissimae- 
Knautietum dipsacifoliae (Poland), Chrysanthemum rotundifolium - Senecio subalpinus community (Poland) (Coldea 1990, 1991; Kliment et al. 2007; Kornaś \& Medwecka-Kornaś 1967; Malinovsky \& Kricsfalusy 2000; Pawłowski et al. 1928; Pawłowski \& Walas 1949; Stuchlik 1968; Winnicki 1999).

Petasites kablikianus Tausch ex Bercht.

This species is subendemic to the Carpathians. It is common and widespread throughout the Western and Eastern Carpathians. It has also some localities in the Sudety Mts and Balkan Peninsula.

This is montane species which is characteristic species to the association Petasiteum kablikiani. It frequently accompanies tall-herb communities in lower altitudes: Aconitetum firmi (Slovakia), Arunco-Doronicetum austriaci (Poland), Cirsio waldsteinii-Heracleetum transsilvanici (Ukraine, Romania), Geranio robertianiDelphinietum elati (Slovakia), Petasiteto kablikiani-Senecietum hercynicae (Slovakia), Ranunculo platanifoliiAdenostyletum alliariae (Poland, Slovakia, Ukraine) (Coldea 1990; 1991; Kornaś \& Medwecka-Kornaś 1967; Malinovsky \& Kricsfalusy 2000; Pawłowski \& Walas 1949; Stuchlik 1968; Winnicki 1999).

\section{Poa granitica Braun-Blanq.}

This species is considered as Pan-Carpathian endemic species by Pawłowski (1972a). According to Slovak botanists two separate taxa exist and $P$. granitica subsp. granitica should be regarded as the Tatra endemic species (after Piękoś-Mirkowa et al. 1996).

Poa granitica s.l. is the alpine species which is characteristic to the association Luzuletum spadiceae. It can be found in tall-herb communities: Aconitetum firmi (Slovakia), Cirsio waldsteinii-Heracleetum transsilvanici (Ukraine), Ranunculo platanifolii-Adenostyletum alliariae (Slovakia) (Coldea 1990, 1991; Deyl 1940; Kliment et al. 2007; Malinovsky \& Kricsfalusy 2000; Pawłowski \& Walas 1949).

\section{Ranunculus pseudomontanus Schur}

This species is Pan-Carpathian subendemic. It is widespread throughout the Western and Eastern Carpathians.

This is alpine species which grows mainly in alpine communities and in tall grass communities in sub-alpine zone. In tall-herb communities it can be found in: Aconitetum firmi (Slovakia), Adenostylo-Doronicetum austriaci (Romania); Galeopsidi speciosae-Rumicetum alpini (Poland), Ranunculo platanifolii-Adenostyletum alliariae (Slovakia) (Coldea et al. 1981; Kliment et al. 2007; Winnicki 1999).

Rumex alpestris Jacq. subsp. carpaticus Zapał.

This species is endemic to the Eastern Carpathians. It is distributed in the Eastern and Southern Carpathians.

This is multizonal mountain species which occurs from foot of the mountains to alpine zone. It grows in various plant communities. In tall-herb communities it is found in: Aconitetum taurici (Romania), AdenostyloAthyrietum dipsacifoliae (Poland), Adenostylo alliariae-Doronicetum austriaci (Romania), Cirsio waldsteiniiHeracleetum transsilvanici (Romania), Diantho compacti-Hypericetum maculati (Poland), Galeopsidi speciosae-Rumicetum alpini (Poland), Ranunculo platanifolii-Adenostyletum alliariae (Ukraine), Trollio altissimae-Knautietum dipsacifoliae (Poland) (Coldea 1990, 1991, Malinovsky \& Kricsfalusy 2000; Pawłowski \& Walas 1949; Stachurska-Swakoń 2008; Winnicki 1999).

\section{Saxifraga carpatica Rchb.}

This is Pan-Carpathian subendemic species. Their localities are restricted to the highest summits of the Eastern and Western Carpathians. It has few localities in Pirin Mts and Rila Mts.

This is alpine species which grows in scree communities. It is occasionally found in Aconitetum firmi (Poland, Slovakia) and Ranunculo platanifolii-Adenostyletum alliariae (Poland, Slovakia) (Kliment et al. 2007; Pawłowski et al. 1928).

\section{Soldanella carpatica Vierh.}

This species is endemic to the Western Carpathians. It is distributed in the Tatra Mts, Malá Fatra Mts, Vel'ká Fatra Mts, Nízke Tatry Mts and Pieniny Mts.

This is multizonal mountain species which is not connected with any plant communities: it occurs as well in forest and non-forest communities. In tall-herb communities it can be found in: Aconitetum firmi (Poland, Slovakia), Adenostylo alliariae-Athyrietum alpestris (Poland, Slovakia), Bryo pseudotriquetri-Chaerophylletum hirsuti (Slovakia), Petasiteto kablikiani-Senecietum hercynicae (Slovakia), Ranunculo platanifoliiAdenostyletum alliariae (Poland, Slovakia) (Balcerkiewicz 1984; Kliment et al. 2007; Kornaś \& MedweckaKornaś 1967; Pawłowski et al. 1928; Stuchlik 1968; Walas et al. 1933). 


\section{Trisetum fuscum Schult.}

This species is endemic to the Carpathians. It is widespread in higher altitudes of the Western and Eastern Carpathians.

This is alpine species which grows in tall grass communities and alpine communites. In tall-herb communities it can be found in: Aconitetum firmi (Slovakia), Aconitetum taurici (Romania), Adenostylo alliariae-Doronicetum austriaci (Romania), Bryo pseudotriquetri-Chaerophylletum hirsuti (Slovakia), Cirsio waldsteinii-Heracleetum transsilvanici (Ukraine),

Ranunculo platanifolii-Adenostyletum alliariae (Slovakia, Ukraine) (Coldea 1990, 1991; Kliment et al. 2007; Pawłowski \& Walas 1949).

\section{Eastern Carpathian-Balkan species}

\section{Campanula abietina Griseb. et Schenk}

This is Eastern Carpathian-Balkan species which occurs in the Eastern, Southern Carpathians and in the Balkan Peninsula.

This is multizonal mountain species. In tall-herb communities it grows in: Aconitetum taurici (Romania), Adenostylo-Doronicetum (Romania), Cirsio waldsteinii-Heracleetum transsilvanici (Romania), Diantho compacti-Hypericetum maculati (Poland), Galeopsidi speciosae-Rumicetum alpini (Poland), Ranunculo platanifolii-Adenostyletum alliariae (Ukraine), Trollio altissimae-Knautietum dipsacifoliae (Poland) (Deyl 1940; Coldea 1990, 1991; Fink 1977; Pawłowski \& Walas 1949; Winnicki 1999).

\section{Dianthus compactus Kit}

This is Eastern Carpathian-Balkan species which occurs in the Eastern, Southern Carpathians and in the Balkan Peninsula.

This is subalpine species, diagnostic species for Diantho compacti-Hypericetum maculati (Poland) and Diantho compacti-Festucetum porcii (Romania). In tall-herb communities it grows also in: Trollio altissimaeKnautietum dipsacifoliae (Poland) (Coldea 1991; Winnicki 1999).

\section{Viola dacica Borb.}

This is Eastern Carpathian-Balkan species which is distributed in the Eastern, Southern Carpathians and in the northern part of the Balkan Peninsula.

This is subalpine species. In tall-herb communities it grows in: Aconitum taurici (Romania) Diantho compacti-Hypericetum maculati (Poland), Galeopsidi speciosae-Rumicetum alpini (Poland) (Boşcaiu 1971; Winnicki 1999).

\section{Eastern biogeographical element in the Polish flora}

\section{Carex dacica Heuff.}

This species occurs in the Eastern and Southern Carpathians, eastern part of the Balkan Peninsula, Asia Minor and Caucasus. It has their western range limit in territory of Poland: in the Bieszczady Mts. The species is listed in the Red List of Vascular Plant in Poland as rare.

This is subalpine species. In tall-herb communities it is found in Aconitum taurici (Romania), Trollio altissimaeKnautietum dipsacifoliae (Poland) (Boşcaiu 1971; Winnicki 1999).

\section{Cirsium waldsteinii Rouy}

This species is distributed in the Eastern and Southern Carpathians, Balkans and eastern part of the Alps. In Poland, their western distribution limit is in the Bieszczady Mts.

The species is listed in Red List of Vascular Plant in Poland as rare.

This is subalpine species. In tall-herb communities it can be found in: Adenostylo-Doronicetum austriacae (Romania), Cirsio waldsteinii-Heracleetum transsilvanici (Romania), Ranunculo platanifolii-Adenostyletum alliariae (Ukraine), Trollio altissimae-Knautietum dipsacifoliae (Poland) (Boşcaiu 1971; Coldea 1990, 1991; Deyl 1940; Malinovsky \& Kricsfalusy 2000; Pawłowski \& Walas 1949; Winnicki 1999).

\section{Scorzonera rosea Waldst. et Kit.}

This species occurs in the Eastern and Southern Carpathians, Balkan Peninsula, Alps, Asia Minor. Their western range limit in Poland is in the territory of the Bieszczady Mts. 
This is subalpine species. In tall-herb communities it can be found in: Diantho compacti-Hypericetum maculati (Poland), Ranunculo platanifolii-Adenostyletum alliariae (Ukraine) (Malinovsky \& Kricsfalusy 2000; Winnicki 1999).

\section{Veratrum album L. subsp. album}

This subspecies is distributed in the Eastern and Southern Carpathians, Balkan Peninsula, Alps and Asia Minor. Their western range limit in Poland is in the territory of the Bieszczady Mts.

This is subalpine taxon. In tall-herb communities it can be found in: Aconitetum taurici (Romania), Adenostylo alliariae-Doronicetum austriaci (Romania), Diantho compacti-Hypericetum maculati (Poland), Galeopsidi speciosae-Rumicetum alpini (Poland), Cirsio waldsteinii-Heracleetum transsilvanici (Romania), Ranunculo platanifolii-Adenostyletum alliariae (Ukraine) (Boşcaiu 1971; Coldea 1990, 1991; Fink 1977; Pawłowski \& Walas 1949; Winnicki 1999).

\section{Summary}

1. Five of the species listed in the Polish Red Book are found in the communities of the Adenostylion alliariae alliance in the Carpathian Mountains.

2. Thirteen endemics and subendemics to the Carpathians are found in tall-herb communities.

3. Fourteen of the thirty taxa which are regarded as eastern element in the Polish flora are found in tall-herb communities.

The combined number of valuable species which grow in the communities of the Adenostylion alliariae alliance reflects the key role of these communities as reservoirs of key species in preserving biodiversity.

Acknowledgement: The author would like to thank Professor Adam Zając and Professor Bogdan Zemanek for their insightful comments on the manuscript. This work was supported by the state Committee for Scientific Research grant number 2P04G 09528.

\section{References}

Aeschimann D., Lauber K., Moser D.M. \& Theurillat J.-P. (2004): Flora alpina. T. 1-3. Haupt Verlag, Bern, Stuttgart, Vienna, T. 1: 1160 pp., T. 2: 1188 pp., T. 3: 324 pp.

Assyov B., Petrova A. (Eds) (2006): Conspectus of the Bulgarian Vascular Flora. Distribution maps and floristic elements. Bulgarian Biodiversity Foundation, Sofia, 453 pp.

Balazs F. (1938-1939): Endemische Pflanzenarten der Karpathen. - Acta Geobotanica Hungarica, 2(1): 1-62.

Balcerkiewicz S. (1984): Roślinność wysokogórska Doliny Pięciu Stawów Polskich w Tatrach i jej przemiany antropogeniczne. Wyd. Nauk. UAM, Ser. Biol. 25, Poznań, 191 pp.

Balcerkiewicz S. \& Pawlak G. (2004): Plant communities of the Babiogórski National Park: High-mountain vegetation. pp. 487-525. In Wołoszyn B.W., Jaworski A. \& Szwagrzyk J. (eds): Babiogórski Park Narodowy, Monografia Przyrodnicza. Komitet Ochrony Przyrody PAN / Babiogórski Park Narodowy, Kraków, 673 pp.

Boşcaiu N. (1971): Flora şi vegetația Munților Țarcu, Godeanu şi Cernei. Editura Academiei Republicii Socialiste România, București, 494 pp.

Coldea G. (1990): Munții Rodnei. Studiu Geobotanic. Editura Academiei Române, Bucureşti, 183 pp.

- (1991): Prodrome des associations vegetales des Carpates du Sud-Est (Carpates Roumaies). -Documents Phytosociologiques N.S. Camerino, 13: 317-539.

Dostál J. (1989): Nová Kvétena ČSSR. Academia Praha, Vol. 1-2: 1548 pp.

Fink H.G. (1977): Pflanzengesellschaften des Schulergebirges (Sudostkarpaten). - Stapfia 2: 1-370.

Hadač E. (1956): Pflanzengesellschaften des Temnosmrečiner Tales in der Hohen Tatra. - Biologické Práce, SAV. Bratislava, 2/1: 1-88 (in Slovak with German summary).

Hegi G. (1958): Illustrierte Flora von Mitteleuropa. Band IV, Teil 1.VIII, Carl Hansen Verlag, 547 pp.

Hultén E. (1968): Flora of Alaska and neighbouring territories. Stanford University Press, California, 1008 pp.

Hultén E. \& Fries M. (1986): Atlas of North European Vascular Plants. North of the Tropic of Cancer. Koeltz Scientific Books, Köenigstein, Vol. 1-3: 1149 pp.

Jalas J. \& Suominen J. (1986, 1989): Atlas Florae Europaeae 1972-1991. Distribution of Vascular Plants in Europe, Helsinki, Vol. 7: 229 pp, Vol. 8: 261 pp.

Jordanov D. (ed) (1963-1997): Flora Reipublicae Popularis Bulgaricae. Vol.1-8, Publ. House of the Bulgarian Academy of Sciences, Sofia, Vol. 1: 478 pp., Vol. 3: 638 pp., Vol. 4: 748 pp., Vol. 8: 518 pp. 
Kliment J., Jarolímek I. \& Šibík J. (2007): Mulgedio-Aconitetea. pp. 21-129. In Kliment J. \& Valachovič M. (eds): Rastlinné spoločenstvá Slovenska. 4. Vysokohorská vegetácia. Veda, Bratislava, $386 \mathrm{pp}$.

Kornaś J. \& Medwecka-Kornaś A. (1967): Plant communities of the Gorce Mts. (Polish Western Carpathians). Natural and seminatural non-forest communities. - Fragm. Flor. Geobot., 13(2): $41-114$ (in Polish with English summary).

Krajčiová-Šibíková I., Šibík, J., Jarolímek I. \& Mišíková K. (2005): The association Adenostylo alliariae-Athyrietum alpestris (Zlatník 1928) Jeník 1961 in the Krivánska Malá Fatra Mts. - Bull. Slov. Bot. Spoločn., 27: 199-206 (in Slovak with English abstract).

Malinovsky K. A. (1980): Rostlinnost wysokogoria ukrainskich Karpat. Naukova Dumka, Kyiv, 238 pp.

Malinovsky K. A. \& Kricsfalusy W. W. (2000): Rostlinnost Ukrainy. T. 1. Wysokogirna rostlinnost. Phytocentre Kyiv, $231 \mathrm{pp}$.

Matuszkiewicz W. (2005): Przewodnik do oznaczania zbiorowisk roślinnych Polski. Wydawnictwo Naukowe PWN, Warszawa, 537 pp.

Meusel H., Jäger E. \& Weinert E. (1965): Vergleichende Chorologie der Zentraleuropäischen Flora. 1. Karten. Veb Gustav Fischer Verlag, Jena, 258 pp.

Meusel H., Jäger E., Rauschert S. \& Weinert E. (1978): Vergleichende Chorologie der Zentraleuropäischen Flora. 2. Karten. Veb Gustav Fischer Verlag, Jena, 259-421 pp.

Meusel H. \& Jäger E. (1992): Vergleichende Chorologie der Zentraleuropäischen Flora. 3. Karten. Veb Gustav Fischer Verlag, Jena, 422-688 pp.

Mitka J. (2003): The genus Aconitum in Poland and adjacent countries. Institute of Botany Jagiellonian University, Kraków, 204 pp.

- (2005): Historical-biogeographical background of endemism of Aconitum (monkshood - Ranunculaceae) in Central Europe. - Roczniki Bieszczadzkie, 13: 41-66 (in Polish with English summary).

Mitka J. \& Nowosad J. (2002): The Delphinium L. genus (Ranunculaceae) in Poland - preliminary results. Roczniki Bieszczadzkie, 10: 233-252 (in Polish with English summary).

Oltean M. \& Dihoru G. (1986): Investigații de cenotaxonomie numerică asupra asociațiilor cu Rumex alpinus L. din Carpații Româneşti. - Stud. Cercet. Biol., Seria Biol. Veg., 38(1): 3-13.

Pacyna A. \& Piękoś H. (1968): Distribution of Campanula serrata (Kit. ap. Schult.) Hendrych in Poland. Fragm. Flor. Geobot., 14(2): 229-235 (in Polish with English summary).

Pawłowska S. (1953): Les espèces endémiques en Pologne et leur protection. - Ochrona Przyrody, 21: 1-33.

- (1972): Charakterystyka statystyczna i elementy flory polskiej. pp. 129-206. In Szafer W. \& Zarzycki K. (eds): Szata roślinna Polski. 1. Państwowe Wydawnictwo Naukowe, Warszawa, 615 pp.

Pawłowski B. (1947): Caractéristique géobotanique générale des Monts de Czywczyn. - Bull. Acad. Pol. Sc. L., Cl. Math.-Nat., Ser. B, (1946): 71-108.

- (1961): Observationes ad genus Symphytum L. pertinentes. - Fragm. Flor. Geobot., 4(1-2): 133-152.

- (1970): Remarques sur l'endemisme dans la flore des Alpes et des Carpates. - Vegetatio, 18: 181-243.

- (1972a): Zespoły wysokogórskie. pp. 366-382. In Szafer W. \& Zarzycki K. (eds): Szata roślinna Polski. 1. Państwowe Wydawnictwo Naukowe, Warszawa, 615 pp.

- (1972b): Szata roślinna gór polskich. pp. 189- 240. In Szafer W. \& Zarzycki K. (eds): Szata roślinna Polski. 2. Państwowe Wydawnictwo Naukowe, Warszawa, 347 pp.

Pawłowski B., Sokołowski M. \& Wallisch K. (1928): Die Pflanzenassoziationen des Tatra-Gebirges. VII Teil: Die Pflanzenassoziationen und die Flora des Morskie Oko-Tales. - Bull. Acad. Pol. Sc. L., Cl. Math.Nat., Ser. B (1927): 205- 272.

Pawłowski B. \& Stecki K. (1927): Die Pflanzenassoziationen des Tatra-Gebirges. IV Teil: Die Pflanzenassoziationen des Miętusia-Tales und des Hauptmassivs der Czerwone Wierchy. - Bull. Acad. Pol. Sc. L., Cl. Math.-Nat., Ser. B, (1925), Suppl. 2: 79-121.

Pawłowski B. \& Walas J. (1949): Les associations des plantes vasculaires des Monts de Czywczyn. - Bull. Acad. Pol. Sc., ser. B, Sci.-Nat. (1948): 117-180.

Piękoś-Mirkowa H., Mirek Z. \& Miechówka A. (1996): Endemic vascular plants in the Polish Tatra Mts. distribution and ecology. - Polish Bot. Stud., 12: 1-107.

Piękoś-Mirkowa H. \& Łobarzewska A. (1990): Cortusa matthioli L. - ecology, threat, and conservation. Studia Naturae, 33: 16-68 (in Polish with English summary).

Prokudin J. N. (ed.) (1999): Opredelitel wyszych rastenij Ukrainy. Fitosocjocentr, Kyev, 546 pp.

Šeffer J. \& Šefferová E. (1989): Communities with Adenostyles alliariae in the High Tatra mountains - a numerical approach. - Biológia, 44(1): 43-50 (in Slovak with English abstract).

Stachurska-Swakoń A. (2008): The role of Athyrium distentifolium Tausch ex Opiz in formation of tall-herb communities in the Tatra National Park (the Western Carpathians). pp. 81-94. In Szczęśniak E. \& Gola E. (eds): Club mosses, horsetails and ferns in Poland - resourses and protection. Polish Botanical Society \& Institute of Plant Biology, University of Wrocław, Wrocław, $253 \mathrm{pp}$. 
- (2009a): Plant communities of the Adenostylion alliariae Br.-Bl. 1926 in the Carpathians - initial results. pp. 125-134. In Holeksa J., Babczyńska-Sendek B. \& Wika S. (eds): The role of geobotany in biodiversity conservation, University of Silesia, Katowice, $375 \mathrm{pp}$.

- (2009b): Syntaxonomical revision of the communities with Rumex alpinus L. in the Carpathians. Phytocoenologia, 39(2): 217-234.

- (2009c): Phytogeographical aspects of grasses occuring in tall-herb vegetation in the Carpathians. pp. 39-47. In Frey L. (ed.): Grass research., W. Szafer Institute of Botany, Polish Academy of Sciences, Kraków. 131 pp.

Stuchlik L. (1968): Tall forb and moss communities of spring of the Polica range (Polish Western Carpathians). - Fragm. Flor. Geobot., 14(4): 485-496 (in Polish with English summary).

Sudnik-Wójcikowska B. \& Werblan-Jakubiec H. (eds) (2004): Gatunki roślin. Poradniki ochrony siedlisk i gatunków Natura 2000 - podręcznik metodyczny. Tom 9. Ministerstwo Środowiska, Warszawa, $227 \mathrm{pp}$.

Szafer W., Pawłowski B. \& Kulczyński S. (1923): Die Pflanzenassoziationen des Tatra-Gebirges. I Teil: Die Pflanzenassoziationen de Chochołowska-Tales. - Bull. Acad. Pol. Sc. L., Cl. Math.-Nat., Ser. B, Suppl.: $1-66$.

- (1927): Die Pflanzenassoziationen des Tatra-Gebirges. III Teil: Die Pflanzenassoziationen des KościeliskaTales. - Bull. Acad. Pol. Sc. L., Cl. Math.-Nat., Ser. B (1923): 13-78.

Szafer W. \& Sokołowski M. (1927): Die Pflanzenassoziationen des Tatra-Gebirges. V Teil: Die Pflanzenassoziationen der nordlich vom Giewont gelegen Taler. - Bull. Acad. Pol. Sc. L., Cl. Math.-Nat., Ser. B, (1925), Suppl. 2: 123-144.

Wilczek Z. (2006): Fitosocjologiczne uwarunkowania ochrony przyrody Beskidu Śląskiego (Karpaty Zachodnie). - Pr. Nauk. Uniw. Śląskiego nr 2418, Wyd. Uniwersytetu Śląskiego, Katowice, 224 pp.

Winnicki T. (1999): Zbiorowiska roślinne połonin Bieszczadzkiego Parku Narodowego (Bieszczady Zachodnie, Karpaty Wschodnie). - Monografie Bieszczadzkie, 4: 1-215 (in Polish with English summary).

Witkowski Z., Król W. \& Solarz W. (eds) (2003): Carpathian List of Endangered Species. WWF and Institute of Nature Conservation, Polish Academy of Science, Vienna-Cracow, 64 pp.

Zając A. \& Zając M. (eds) (2001): Distribution Atlas of Vascular Plants in Poland. Laboratory of Computer Chorology, Institute of Botany, Jagiellonian University, Cracow, 715 pp.

Zarzycki K. \& Szelagg Z. (2006): Red list of the vascular plants in Poland. pp. 11-20. In Mirek Z., Zarzycki K., Wojewoda W. \& Szeląg Z. (eds): Red list of the plants and fungi in Poland. W. Szafer Institute of Botany, Polish Academy of Sciences, Kraków, 99 pp.

Zemanek B. (1991): The phytogeographical division of the Polish East Carpathians. - Zesz. Nauk. UJ., Prace Bot., 22: 81-119.

- (2005): Eastern biogeographical element in flora and vegetation of the Bieszczady National Park. - Roczniki Bieszczadzkie, 13: 29-40 (in Polish with English summary).

Zemanek B. \& Winnicki T. (1999): Vascular plants of the Bieszczady National Park. - Monografie Bieszczadzkie, 3: 1-249 (in Polish with English summary).

Author's address: Alina Stachurska-Swakoń, Institute of Botany, Jagiellonian University, ul. Kopernika 27, 31-501 Kraków, Poland, e-mail: alina.stachurska-swakon@uj.edu.pl 